\title{
Assessment of Patients with Hepatitis D
}

\author{
Delta Hepatitlerinin Değerlendirilmesi
}

\author{
Emine PARLAK1, Ayşe ERTÜRK2, Mehmet PARLAK1, Zahide KOŞAN3, Ayşe ALBAYRAK1, \\ Zülal ÖZKURT1 Kemalettin ÖZDEN1, Serpil EROL4
}

${ }^{1}$ Atatürk University Faculty of Medicine, Department of Infectious Diseases and Clinical Microbiology, Erzurum, Turkey

2Recep Tayyip Erdoğan University Faculty of Medicine, Department of Infectious Diseases and Clinical Microbiology, Rize, Turkey

${ }^{3}$ Atatürk University Faculty of Medicine, Department of Public Health, Erzurum, Turkey

${ }^{4}$ Haydarpaşa Numune Training and Research Hospital, Clinic of Infectious Diseases and Clinical Microbiology, Istanbul, Turkey

\begin{abstract}
Objective: Hepatitis delta virus (HDV) is the smallest known virus to infect humans. HDV, a defective ribonucleic acid (RNA) virus, is also the most important cause of liver-related mortality in patients with hepatitis B. Fifteen-20 million people worldwide are estimated to be infected with HDV. In this study, we aimed to determine the epidemiological and clinical manifestations of HDV infection and to asses the data on clinical and laboratory findings, treatments, serologies and biopsy results in patients with HDV infection.

Materials and Methods: The records of patients with HDV infection who attended the infectious diseases and clinical microbiology clinics at Atatürk University Medical Faculty Hospital between 2008 and 2013 were retrospectively analyzed. Antigen and antibody results were investigated using enzyme-linked immunosorbent assay (ELISA) (Dia. Pro Diagnostic Bioprobes Srl, Milan, Italy). Determination of hepatitis $B$ virus (HBV) DNA values and HDV RNA (Qiagen ${ }^{\odot}$, Germany) was performed using real-time polymerase chain reaction. Liver biopsies were performed and the specimens were assessed using Knodell's scoring system.

Results: Two thousand five hundred forty hepatitis B surface antigen (HBsAg)-positive patients were included in the study. One hundred and three $(4.05 \%)$ patients (35 female -34\%-and 68 male66\%-) aged between 19 and 70 years (median: 49 years) were HDV antibody (anti HDV)-positive. Cirrhosis developed in 10 (9.7\%) patients. Sixty (58.3\%) patients were anti HBe-positive, while 34 (33\%) were hepatitis B e antigen $(\mathrm{HBeAg})$ and anti-hepatitis B e (anti-HBe) negative.

Conclusion: HDV should be investigated in patients with hepatitis $B$ due to its association with the increased risk of progression to liver cirrhosis (LC) and hepatocellular carcinoma, as well as mortality rates. Hepatitis $D$ is still a significant problem in Turkey and especially in our region. Nationwide hepatitis B vaccination programs and frequent screening of blood specimens will prevent hepatitis $D$.

Keywords: Hepatitis B virus, hepatitis D virus, hepatitis delta, fibrosis,
\end{abstract} co-infection, interferon, superinfection
ÖZ

Amaç: Hepatit delta virüsü (HDV), insanları enfekte ettiği bilinen en küçük virüstür. Aynı zamanda hepatit B hastalarında karaciğer ilişkili mortalitenin en önemli nedenidir. HDV defektif bir ribo nükleik asit (RNA) virüsüdür. Dünyada 15-20 milyon insanın delta ile enfekte olduğu tahmin edilmektedir. Delta hepatitli olgularımıın epidemiyolojik ve klinik yansımalarını belirlediğimiz çalışmamızda bu hastaların klinik, laboratuvar verilerini, tedavilerini, serolojilerini ve biyopsi sonuçlarını değerlendirmeyi amaçladık.

Gereç ve Yöntemler: Atatürk Üniversitesi Tıp Fakültesi Hastanesi, Enfeksiyon Hastalıkları ve Klinik Mikrobiyoloji servisine 2008-2013 tarihleri arasında başvuran delta hepatit hasta dosyaları retrospektif olarak incelendi. Antijen ve antikor sonuçları enzyme-linked immunosorbent assay (ELISA) (Dia. Pro Diagnostic Bioprobes Srl, Milan, Italy) yöntemi ile araştıııldı. HBV-DNA'nın ve HDV RNA'nın (Qiagen ${ }^{\odot}$, Germany) belirlenmesi polimeraz zincir reaksiyonu, yöntemleri ile yapıldı. Olgulara karaciğer biopsisi uygulandı. Patolojileri Knodell ile değerlendirildi.

Bulgular: Çalışmaya $2540 \mathrm{HBsAg}$ pozitif hasta dahil edildi. Yüz üç $(\% 4,05)$ anti HDV pozitif bulundu. Bu 103 hastanın yaşları 19-70 (ortalama 49 yıl) arasında olup, 35'i kadın (\%34), 68'i (\%66) erkek idi. Hastalardan 10 'unda $(\% 9,7)$ siroz gelişti. Anti-HBe pozitif 60 (\%58,3) hasta varken 34 (\%33) hastada $\mathrm{HBeAg}$ ve anti $\mathrm{HBe}$ negatif bulundu. Sonuç: Hepatit B'li hastalarda siroza, hepatosellüler karsinomaya (HK) gidişi ve mortaliteyi arttırdığı için delta virüsü mutlaka araştırımalıdır. Ülkemiz ve özellikle bölgemiz için önemli bir sorundur. Delta hepatitine karşı korunmak için hepatit B aşı programlarına uyulmalı ve kan örnekleri taranmalıdır.

Anahtar Kelimeler: Hepatit B virüsü, hepatit D virüsü, delta hepatitis, fibrosis, koenfeksiyon, interferon, süperenfeksiyon 


\section{Introduction}

Hepatitis delta virus (HDV) was first described by Rizzetto et al. (1) in 1977 (2). The genome of HDV is the smallest known to infect humans (3). HDV that can cause infection only in the presence of $\mathrm{HBV}$ is a defective agent requiring $\mathrm{HBV}$ for replication $(4,5,6,7)$. Transmission is by the parenteral, vertical or horizontal routes $(4,8)$. Hemodialysis, intravenous drug use, homosexuality and prostitution are among the risk factors (9). HDV infection generally suppresses hepatitis B virus (HBV) viral replication. It can lead to hepatitis $B$ e antigen ( $\mathrm{HBeAg}$ ) negativity, anti-hepatitis $\mathrm{B}$ e (anti-HBe) positivity chronic hepatitis $\mathrm{B}$ and low titer HBV DNA positivity. HDV infection is more serious condition than hepatitis B monoinfection. Severe necroinflammatory reaction is seen in acute HDV infection $(3,4,10)$. Hepatitis $D$, which may cause chronic hepatitis, liver cirrhosis (LC) and hepatocellular carcinoma $(\mathrm{HCC})$, is an important health problem worldwide. It is estimated that 15-20 million people in the world are infected with $\operatorname{HDV}(3,8,9,11)$. It is particularly prevalent in Eastern and Southeastern Anatolia in Turkey $(3,12,13)$. HDV genotype 1 is widespread in Turkey $(3,5,13)$. Interferon-alpha is currently the only approved treatment option in HDV (5). Patients infected with HDV are at higher risk of developing fulminant hepatitis than those infected with other hepatitis viruses, while cirrhosis and terminal liver failure are more prevalent in the chronic form $(4,11)$. In a study, co-infection could not be differentiated from superinfection in $73 \%$ of cases (8). HDV is the most important cause of liver-related mortality in patients with hepatitis $B(3,5)$. It is thought that the prevalence of HDV infection is higher than that has been reported in Turkey (12). The number of studies on hepatitis $D$ from our region is limited. We think that this study will provide important data regarding the epidemiology of the disease. The purpose of this study was to analyze the data on clinical, serological and laboratory findings, treatment, and biopsy results in patients with hepatitis $D$ who attended the infectious diseases and clinical microbiology clinics at Atatürk University Medical Faculty Hospital between 2008 and 2013.

\section{Materials and Methods}

We retrospectively evaluated patients with hepatitis D who attended at the Atatürk University Faculty of Medicine Department of Infectious Diseases Clinic between January 2008 and December 2013.

\section{Exclusion Criteria}

Pregnant patients and those with autoimmune hepatitis, a history of alcohol use, human immunodeficiency virus (HIV) infection, metabolic causes or hemochromatosis were excluded.

\section{Assessed Criteria}

We recorded patients' age, gender, region of presentation, HBV DNA and HDV RNA levels obtained using real-time polymerase chain reaction (RT-PCR), serological data on hepatitis B surface antigen (HBsAg), HBeAg and anti-HBe, HDV antibody (anti HDV) measurement, transaminases, time of diagnosis of hepatitis $B$ and $D$, treatments administered and whether or not HCC developed. Histology activity index (HAl) and fibrosis levels in cases in which liver biopsy were performed were also investigated. The Knodell scoring system was used to calculate the liver $\mathrm{HA}$.

Hepatitis B Virus DNA and Hepatitis Delta Virus Ribonucleic Acid Measurement Technique

Anti HDV, serological markers of hepatitis B infection (HBsAg, $\mathrm{HBeAg}$ and Anti-HBe) were determined using ELISA (Dia. Pro; Diagnostic Bioprobes, Italy). Serum HBV DNA and HDV RNA were determined using the RT-PCR method (QIAGEN, Hilden, Germany).

\section{Statistical Analysis}

IBM SPSS software version 20 (SPSS, Chicago, IL, USA) was used for statistical analysis. Descriptive analysis was performed. Standard deviation, mean, median, frequency and percentage were calculated.

\section{Treatment Administered}

Patients with dominant HDV infection received pegylated interferon (peg-IFN) alpha or classic interferon, and cases with dominant HBV infection received oral antivirals for varying durations. Abdominal ultrasound was performed. Liver biopsy was performed in the majority of cases. Histopathology was assessed with the Knodell classification. Liver biopsy was taken percutaneously by ultrasound-guided radiology. Biopsy materials were analyzed at the pathology laboratory and degree of fibrosis was determined using the modified Knodell scoring system and $\mathrm{HAl}$.

\section{Results}

Two thousand five hundred fourty patients with hepatitis $B$ were investigated in this period, 1555 (61.2\%) subjects were male and 985 (38.8\%) were female. The mean age and median age of the patients were $43.95 \pm 13.22$ and 43 , respectively.

\begin{tabular}{|l|l|}
\hline \multicolumn{2}{|l|}{ Table 1. Demographic data and laboratory data of the patients } \\
\hline $\begin{array}{l}\text { Mean age of patients diagnosed } \\
\text { with HDV }\end{array}$ & $47.41 \pm 12.79$ (median 49) \\
\hline $\begin{array}{l}\text { Mean age of patients diagnosed } \\
\text { with HBV }\end{array}$ & $43.94 \pm 13.24$ (median 43) \\
\hline ALT & $94.12 \pm 75.73$ \\
\hline AST & $73.55 \pm 64.11$ \\
\hline Anti-HBe positive & $60(58.3 \%)$ \\
\hline $\begin{array}{l}\text { HBeAg and anti HBe negative } \\
\text { patients }\end{array}$ & $34(33 \%)$ \\
\hline HBV DNA IU/ml & $3449908.09 \pm 29928971.38$ \\
\hline HDV RNA IU/ml & $891960.22 \pm 6815226.84$ \\
\hline HAl & $5.31 \pm 4.96$ (median 6) \\
\hline Fibrosis & $1.57 \pm 1.56$ (median 1) \\
\hline
\end{tabular}

HDV: Hepatitis D virus, HBV: Hepatitis B virus, ALT: Alanine aminotransferase, AST: Aspartate aminotransferase, HBeAg: Hepatitis B e antigen, HAl: Histology activity index 
One hundred three HDV infections were observed in the same period. The seropositivity rate of delta infection among the patients with hepatitis B was $4.05 \%$. Demographic and laboratory data of patients with HDV infection are shown in Table 1. LC developed in 10 (9.7\%) patients. HBV, hepatitis C virus $(\mathrm{HCV})$ and $\mathrm{HDV}$ co-infection was present in one patient.

\section{Discussion}

Three hundred fifty million people per year are infected with hepatitis $B$, and 1 million people die from the infection every year. HDV, a defective RNA virus, depends on HBV for its life cycle $(5,6,14)$. It is the least common chronic hepatitis agent (6). LC, HCC, mortality and morbidity rates are high $(5,6)$. Hepatitis $D$ has been shown to increase mortality rate in HBeAg-negative hepatitis cases (6). Patients with hepatitis $B$ must be screened in terms of HDV because of these poor outcomes (3). The overall prevalence of HDV infection has been decreased in general population (15), however, it is still a significant health problem in the Asian Pacific region and, Iran and Pakistan are countries where there has been no decrease in high prevalences. In China, Turkey, Australia, Japan, India and Taiwan, the prevalence of infection is decreasing, but the infection still occurs $(9,14,16)$. Turkey is among the moderately endemic countries (13). Although the prevalence of the disease is decreasing due to widespread hepatitis vaccination, sterile procedures and injection, improved socioeconomic status, prevention strategies, and public education campaigns, it remains a major public health issue $(5,9,11)$. There are differences in distribution of the disease between the regions in Turkey. It is a more severe problem in Eastern and Southeast Anatolia in Turkey, and in regions with lower socioeconomic levels $(13,15,17)$. In a study from the Van region it has been stated that $80 \%$ of cases were living in rural areas (17). Patients presenting from outside of the city represented $59.2 \%$ of cases. This data is compatible with that in our study.

HDV infection has been reported to be more widespread in males than in females $(4,14,17)$. In our study, in our cases, most of the patients (about 66\%) were male. It may be due to the fact that men start work life earlier and men lead more risky lifestyles, such as intravenous drug use, than do females. The prevalence of hepatitis $D$ has been found to be higher among unmarried individuals and in those who were employed by the non-governmental organizations $(6,14)$. The prevalence is also high among individuals having multiple sexual partners, homosexuals, prostitutes, those receiving hemodialysis, HIVpositive patients and those using intravenous drugs $(9,14)$. Low levels of vaccination are reported among intravenous drug users, with a prevalence of HDV of 54-34.5\%. The Centers for Disease Control and Prevention (CDC) recommends that drug users be screened for HBV (2). In addition, hepatitis D represents an additional problem for HIV-positive individuals and hemodialysis patients (13).

The Turkish Association for the Study of the Liver screened 5471 people from different regions of Turkey. Anti-HDV IgG positivity was determined in $2.7 \%$ of subjects (18), 29960 people were screened in Turkey between 2009 and 2011 within the scope of the "Bus Project" conducted by the Association of Viral Hepatitis. Anti-HDV IgG was investigated in 1805 HBsAg-positive individuals and it was found that a total of 43 subjects (2.39\%) were anti-HDV positive. Anti-HDV positivity was significantly higher in subjects of advanced age and in the Eastern and Southeastern regions (19).

The anti HDV positivity rate in Turkey as a whole is $3 \%$ among patients with acute viral hepatitis, $8.8 \%$ among patients with acute viral hepatitis B (AVH-B), 20\% in individuals with chronic hepatitis B (CHB), 32.5\% in those with LC and $23 \%$ patients with HCC. Anti HDV positivity rate in patients with LC in Van and in Diyarbakır has been detected to be $30 \%$ and $59.4 \%$, respectively. Anti HDV positivity rate in patients with hepatitis B has been observed at levels of $45 \%$ in Diyarbakır, $37.5 \%$ in Elazığ and $4.05 \%$ in Erzurum while it was $2.3 \%$ in Istanbul and $2.5 \%$ in Izmir. The difference between Eastern and Western parts of Turkey was significant (15). A study from Switzerland reported anti HDV positivity in $5.9 \%$ of 1699 patients with hepatitis B (8). Anti HDV positivity was determined in $45.5 \%$ of 292 patients with hepatitis B in Elazığ (20). In a study from Erzurum performed in 2002, anti HDV positivity rate among carriers of hepatitis $B$ was reported to be $1.2 \%$ (15). In a study investigating the prevalence of HDV in 112 patients with HBV infection, Kaya (21) has reported that $3.3 \%$ of 30 chronic hepatitis B patients were anti-HDV-positive. Anti HDV positivity rate of $33.3 \%$ was reported among patients with chronic hepatitis in Van (17). HDV was identified in $1.76 \%$ of 170 children with HBV in Izmir. Familial transmission was shown in all cases (22). Anti HDV positivity rate of $10.3 \%$ was determined in 145 patients with hepatitis B in Van (23). Since HDV diagnosis and serology are difficult and there are no standards, it is thought that infection levels may be higher than estimated (8). Anti HDV positivity rate among our entire hepatitis B study group was $4.05 \%$, irrespective of whether patients had chronic hepatitis, cirrhosis or hepatocellular cancer. The figures show regional variations. The level in our region was lower than that reported in other provinces. The level in our province is low $(4.05 \%)$, in association with public education activities, and high rates of vaccination and sociocultural levels. There may be variations between provinces within the region. The study years and groups vary. Although the level was lower than in other provinces in the region, close monitoring is essential since the disease involves high levels of mortality and morbidity. We think that the decrease in the prevalence of HDV infection may be due to the fact that prevention methods and HBV vaccination programs have become widespread in public.

Histopathological injury in the liver is greater in patients with hepatitis D. It may cause portal and parenchymal inflammatory changes (24). Evaluation of necroinflammation and fibrosis in a specimen depends on suitability of the part, the pathologist and the proficiency involved (16). Injury in liver histopathology increases in HDV-positive cases (24). 
HDV RNA is the first marker to become positive. An HDV infection does not always mean active HDV infection. Demonstration of presence of HDV RNA with PCR is the most sensitive method showing active HDV infection (25). There is no standardization of the reverse transcriptase PCR test recommended by the World Health Organization (WHO) (26). Decrease or loss of IgM exhibits remission in chronic delta infection. HDV RNA loss accompanies a fall in lgM titers (5). HDV is generally the dominant virus in HBV-HDV coinfection (24). HDV RNA positive was detected in serum sample with acute HDV. HBV DNA positivity may rarely occur with HBV domination over HDV (27). The natural process involved in HDV infection is not completely clear. Serological tests for the detection of HDV replication lack sensitivity. Anti HDV negativity when HDV RNA is positive is known as "occult HDV" (16). HDV antibody was positive in 86 out of $153 \mathrm{HBsAg-positive} \mathrm{patient}$ specimens, and HDV RNA positivity was determined in $21.5 \%$. ALT elevation and HDV IgM positivity have been suggested to be useful in predicting delta viremia (25).

There is no specific antiviral treatment. The only proven effective therapy in HDV infection is interferons $(10,11)$. The rate of response to treatment ranges between $10 \%$ and $30 \%$ $(5,8)$. Recent publications have also shown the effectiveness of peg-IFN alpha. There have been studies showing that combined therapy was not superior to interferon monotherapy (26). When HBV is active or dominant, nucleoside/nucleotide analogs should be added to interferon therapy $(22,26,28)$. Lamivudin, ribavirin, suramin, acyclovir, famciclovir, thymosin, steroids, levamisole, and thymic humoral factor gamma 2 have not been found to be useful in the treatment of HDV infection $(11,29)$. Hepatitis $D$ require long-term treatment (30). The length of treatment recommended in some studies is not less than 2 years. It has been reported that response to treatment cannot be estimated in advance. Response may sometimes improve after treatment (24). For the patients who had dominant HDV (60 cases), Peg-INF treatment was used. We believe that oral nucleoid treatment is useful for patients with dominant hepatitis B. For some cases, interferon and/or nucleosis treatments (49 cases) were applied.

\section{Conclusion}

Hepatitis D is the least common but most severe form of viral hepatitis. Although the number of patients with HDV infection is decreasing, it is still a significant health issue in Turkey. If not treated, speed of transformation into fulminant disease and cirrhosis is greater in the presence of HDV. These patients must be frequently and closely monitored for complications. The condition must be considered in cases of $\mathrm{CHB}$ and cases of hepatitis $B$ in which cirrhosis develops rapidly. Since there is no effective treatment, hepatitis $B$ vaccination must be performed in order to protect healthy individuals and relatives of patients with HBV. Migrants, people living in endemic areas, intravenous drug users and patients with LC, HCC and acute and chronic hepatitis must be screened for HDV.

\section{Authorship Contributions}

Ethics Committee Approval: The study was approved by the Atatürk University of Local Ethics Committee, Informed Consent: Consent form was filled out by all participants, Concept: Emine Parlak, Mehmet Parlak, Design: Emine Parlak, Data Collection or Processing: Emine Parlak, Ayşe Ertürk, Analysis or Interpretation: Emine Parlak, Zahide Koşan, Literature Search: Emine Parlak, Ayşe Albayrak, Kemalettin Özden, Zülal Özkurt, Serpil Erol, Writing: Emine Parlak, Peerrewiev: External and Internal peer-reviewed, Conflict of Interest: No conflict of interest was declared by the authors, Financial Disclosure: The authors declared that this study has received no financial support.

\section{References}

1. Rizzetto M, Canese MG, Aricò S, Crivelli O, Trepo C, Bonino $F$, Verme G. Immunofluorescence detection of new antigen antibody system (S/anti-5) associated to hepatitis B virus in liver and in serum of HBsAg carriers. Gut. 1977;18:997-1003.

2. Holmberg SD, Ward JW. Hepatitis Delta: seek and ye shall find. J Infect Dis. 2010;202:822-824.

3. Bulut $\mathrm{Y}$, Bahcecioglu IH, Aygun $\mathrm{C}$, Oner PD, Ozercan I, Demirdag K. High genetic diversity of hepatitis delta virus in eastern Turkey. J Infect Dev Ctries. 2014;8:74-78.

4. Khan AU, Waqar M, Akram M, Zaib M, Wasim M, Ahmad S, Niaz Z, Ali S, Ali H, Idrees M, Bajwa MA. True prevalence of twin HDV-HBV infection in Pakistan: a molecular approach. Virol J. $2011 ; 8: 420$.

5. Kose S, Ece G, Gozaydin A, Turken M. Study on seroprevalence of hepatitis delta in a regional hospital in western Turkey. J Infect Dev Ctries. 2012;6:782-785.

6. Dülger $A C$, Atmaca $M$, Kemik Ö, Küçükoğlu ME, Avcu S. Epidemiologic and Clinical Aspects of Delta Hepatitis in the Van Region. Van Tip Derg. 2010;17:32-35.

7. Pollicino T, Raffa G, Santantonio T. Replicative and Transcriptional Activities of Hepatitis B Virus in Patients Coinfected with Hepatitis B and Hepatitis Delta Viruses. J Virol. 2011;85:432-439.

8. Genné D, Rossi I. Hepatitis delta in Switzerland: a silent epidemic. Swiss Med Wkly. 2011;141:w13176.

9. Abbas Z, Jafri W, Raza S. Hepatitis D: Scenario in the AsiaPacific region. World J Gastroenterol. 2010;16:554-562.

10. Yurdaydın C, Idilman R, Bozkaya H, Bozdayi AM. Natural history and treatment of chronic delta hepatitis. J Viral Hepat. 2010;17:749-756.

11. Taylor JM. Hepatitis delta virüs. Virology. 2006:344;71-76.

12. Değertekin H, Yükselen AV, Dursun M, Yalçın K. Seroepidemiology of delta hepatitis in Turkey. Turk J Gastroenterol. 1999;10:316327.

13. Tosun S. The change in epidemiological pattern of hepatitis delta virus infection and the current stiuation in our country. Viral Hepatitis Journal. 2013;19:1-7.

14. Seifi SJ, Ghannad MS. A Study of HDV in HBsAg positive patients in Tabriz, Northwestern Iran. Hepat Mon. 2010;10:110115.

15. Değertekin H, Yalçin K, Yakut M. The prevalence of hepatitis delta virus infection in acute and chronic liver diseases in Turkey: an analysis of clinical studies. Turk J Gastroenterol. 2006; 17:25-34.

16. Alavian SM. Unthought-of Problems Regarding Hepatitis D Virus Infection. Hepat Mon. 2010;10:77-79. 
17. Türkdoğan $K$, Akdeniz $H$, Berktas $N$, Tuncer I, Irmak H, Buzgan $\mathrm{T}$, Akdeniz $\mathrm{H}$. Hepatitis delta virus infection inVan region of Eastern Turkey. Turk J Gastroenterol. 1999;10:84-88.

18. Tözün N, Özdoğan $O$, Çakaloğlu Y, Idilman R, Karasu Z, Akarca $U$, et al. A nationwide prevalence study and risk factors for Hepatitis A, B, C and D Infections in Turkey. The 61st Annual Meeting of the American Association for the Study of Liver Diseases: The Liver Meeting $®$ 2010. October 29 November 2 2010, Boston USA, Poster No: 789, Hepatology Vol 52 S1:697 A.

19. Örmeci N, Balık I, Tabak F, Saltoğlu N, Tosun S, Şencan I, et al. Otobüsle dolaşılan illerdeki HBsAg pozitif kişilerdeki HDV sonuçları. X. Ulusal Viral Hepatit Kongresi Antalya, 01-04 Nisan 2010, s.173, P18-04.

20. Bahçecioglu IH, Aygun C, Gozel N, Poyrazoglu OK, Bulut Y, Yalniz M. Prevalence of hepatitis delta virus (HDV) infection in chronic hepatitis B patients in eastern Turkey: still a serious problem to consider. J Viral Hepat. 2011;18:518-524.

21. Kaya S. Our Prevalence of Anti-HDV in Outpatients with Chronic Hepatitis B. Viral Hepatitis Journal. 2006;11:154-157.

22. Özgenç F, Ecevit ÇÖ, Erdem G, Sertöz R, Yağcı RV. Prevelance of hepatitis $D$ co-enfection in children with hepatitis $B$ infection: Cross-sectional analyses from Western Turkey. Turk J Gastroenterol. 2013;24:345-348.

23. Berktaş M, Parlak M, Çıkman A, Yüce M, Yaman G. Prevalence of HDV-RNA in HBV-DNA Positive Patients. Viral Hepatitis Journal. 2012;18:34-36.

24. Ceylan B, Fincancı M, Müderrisoğlu C, Soysal F, Eren G. Evaluation of Long-Term Follow-Up Results of the Patients with Anti-HDV Positivity. Viral Hepatitis Journal. 2007;12:95-102.

25. Özekinci T, Atmaca S, Akpolat N, Temiz H, Arıkan E. Short communication: evaluatıon of the correlatıon between Hepatitis D virus RNA positivity and HDV antibodies. Mikrobiyol Bul. 2005;39:345-349.

26. Diagnosis and Treatment of Chronic Hepatitis D infection. Viral Hepatitis Journal. 2011;17:111-116.

27. Modahi LE, Lai MM. Hepatitis delta virus: The molecular basis of laboratory. Crit Rev Clin Lab Sci. 2000;37:42-45.

28. Lok ASF and McMahon BJ. Chronic hepatitis B. AASDL Practice Guidelines. Hepatology. 2007;45:507-539.

29. Niro GA, Rosina F, Rizzetto M. Treatment of hepatitis D. J Viral Hepat. 2005;12:2-9.

30. Price J. An Update on Hepatitis B, D, and E Viruses. Top Antivir Med. 2014;21:157-163. 